\title{
ANALISIS POTENSI EKONOMI DAN STRUKTUR PEREKONOMIAN KABUPATEN JEMBER TAHUN 2005 - 2009
}

Oleh :

TAUFIK HIDAYAT *)

\begin{abstract}
ABSTRAK
Pembangunan nasional di negara-negara berkembang pada umumnya, terfokus pada pembangunan ekonomi melalui usaha pertumbuhan ekonomi. Pertumbuhan ekonomi berkaitan erat dengan peningkatan produksi barang dan jasa, yang diukur antara lain melalui Produk Domestik Bruto (PDB) pada tingkat nasional dan Produk Domestik Regional Bruto (PDRB) pada tingkat daerah baik Propinsi, Kabupaten maupun Kota. Peranan setiap sektor ekonomi dalam perekonomian dapat diketahui dari angka distribusi prosentase Produk Domestik Regional Bruto (PDRB) Atas Dasar Harga Berlaku (ADHB). Tujuan penelitian ini adalah untuk mengetahui perkembangan PDRB selama 5 tahun (Tahun 2005-2009) pada masing-masing sektor, mengetahui sektor basis ekonomi dan mengetahui sektor-sektor ekonomi mana yang potensial untuk dikembangkan sebagai penunjang pertumbuhan ekonomi di Kabupaten Jember. adapun Data utama yang digunakan untuk menganalisis Analisis Potensi Ekonomi dan Struktur Perekonomian Kabupaten Jember Tahun 2005- 2009 adalah data skunder yang bersumber BPS dan Pemda Kabupaten Jember, Data yang dianalisis adalah data data PDRB Kabupaten Jember dan PDRB Propinsi Jawa Timur Tahun 2005-2009 atas dasar harga berlaku dan atas dasar harga konstan.
\end{abstract}

Kata Kunci: Pembangunan Ekonomi, Pembangunan Ekonomi, Produk Domestik Bruto 


\section{PENDAHULUAN}

Pembangunan nasional di negara-negara berkembang pada umumnya, terfokus pada pembangunan ekonomi melalui usaha pertumbuhan ekonomi. Pertumbuhan ekonomi berkaitan erat dengan peningkatan produksi barang dan jasa, yang diukur antara lain melalui Produk Domestik Bruto (PDB) pada tingkat nasional dan Produk Domestik Regional Bruto (PDRB) pada tingkat daerah baik Propinsi, Kabupaten maupun Kota. Pembangunan nasional mempunyai dampak atas pembangunan daerah, sebab daerah adalah bagian integral dari suatu negara.Indonesia sebagai suatu negara kesatuan, rencana pembangunannya meliputi rencana pembagunan nasional maupun rencana pembangunan dalam tataran regional.Pembangunan ekonomi nasional mempunyai dampak atas struktur ekonomi nasional dan struktur ekonomi daerah.

Pembangunan ekonomi daerah adalah suatu proses dimana pemerintah daerah dan masyarakatnya mengelola sumber daya yang ada dan membentuk suatu pola kemitraan antara pemerintah daerah dengan sektor swasta untuk menciptakan suatu lapangan kerja baru dan merangsang perkembangan pertumbuhan ekonomi dalam wilayah tersebut.

Seperti diketahui bersama, krisis yang melanda Indonesia sejak periode 1997, membawa dampak negatif ke dunia perekonomian nasional umumnya, dan perekonomian regional khususnya.Krisis ini menyebabkan terjadinya perubahan dari nilai tambah sektor-sektor yang ada di wilayah nasional juga di wilayah daerah.Sehingga pemerintah pusat mengeluarkan kebijakan otonomi daerah yangditandai dengan lahirnya dua produk undang-undang, yaitu Undang-undang. No.22 Tahun 1999 tentang Pemerintahan Daerah yang menimbang : a). bahwa sistem pemerintahan Negara Kesatuan Republik Indonesia menurut Undang-Undang Dasar 1945 memberikan keleluasaan kepada Daerah untuk menyelenggarakan Otonomi Daerah; b). bahwa dalam penyelenggaraan Otonomi Daerah, dipandang perlu untuk lebih menekankan pada prinsip-prinsip demokra-si, peran-serta masyarakat, pemerataan dan keadilan, serta memperhatikan potensi dan keanekaragaman Daerah dan Undang-undang 32 tahun 2005 tentang pemerintah yang menimbang : a). bahwa efisiensi dan efektivitas penyelenggaraan pemerintahan daerah perlu ditingkatkan dengan lebih memperhatikan aspek-aspek hubungan antar susunan pemerintahan dan antar pemerintahan. daerah, potensi dan keanekaragaman daerah, peluang dan tantangan persaingan global dengan memberikan kewenangan yang seluas-luasnya kepada daerah disertai dengan pemberian hak dan kewajiban menyelenggarakan otonomi daerah dalam kesatuan sistem penyelenggaraan pemerintahan negara; b). bahwa Undang-Undang Nomor 22 Tahun 1999 tentang Pemerintahan Daerah tidak sesuai dengan perkembangan keadaan, ketatanegaraan, dan tuntutan penyelenggaraan otonomi daerah sehingga perlu diganti. Lahirnya undang-undang tersebut disambut positif oleh banyak kalangan dengan segenap harapan bahwa melalui otonomi daerah akan dapat merangsang terhadap adanya upaya untuk menghilangkan praktik-praktik sentralistik yang pada satu sisi dianggap kurang menguntungkan bagi daerah dan penduduk lokal. Era otonomi telah memberikan kesempatan kepada pemerintah daerah, baik provinsi maupun kabupaten/kota untuk mengembangkan sendiripotensi daerah yang dimiliknya. Dengan kata lain, daerah diberi wewenang untuk mengelola sendiri keuangannya sekaligus menentukan arah pembangunan yang akan dilaksanakan demi tercapainya kemakmuran penduduk di wilayahnya, dengan mempertimbangkan segenap potensi, sumber daya serta faktor-faktor lainnya, baik faktor pendukung maupun faktor penghambat. Dengan demikian suatu daerah sangat memerlukan beragam data yang dapat dijadikan sebagai dasar acuan, baik dalam penyusunan evaluasi pembangunan ekonomi di daerah.

Dengan melakukan penelitian terhadap struktur ekonomi potensi wilayah di Kabupaten Jember, maka akan diketahui pergeseranpergeseran pada sektor-sektor ekonomi di Kabupaten Jember tersebut, serta mengetahui sektor-sektor potensial di daerah tersebut, sehingga Pemerintah Daerah dapat memprioritaskan perencanaan pembangunan terhadap seluruh sektor-sektor baik yang menjadi sektor potensial maupun yang tidak potensial dalam struktur perekonomian di Kabupaten Jember. Untuk sektor yang potensial diharapkan mampu mengangkat sektor-sektor yang lain untuk lebih maju lagi, sehingga pergeseran sektoral dalam perekonomian Kabupaten Jember dapat berjalan bersamaan meskipun dengan tingkat perkembangan yang berbeda-beda. tulisan ini bertujuan untuk mengetahui perkembangan PDRB selama 5 tahun (Tahun 2005-2009) pada masing-masing sektor, mengetahui sektor basis ekonomi dan mengetahui sektor-sektor ekonomi mana yang potensial untuk dikembangkan sebagai penunjang pertumbuhan ekonomi di Kabupaten Jember. 


\section{METODE PENELITIAN}

Data utama yang digunakan untuk menganalisis Analisis Potensi Ekonomi dan Struktur Perekonomian Kabupaten Jember Tahun 2005- 2009 adalah data skunder yang bersumber BPS dan Pemda Kabupaten Jember, Data yang dianalisis adalah data data PDRB Kabupaten Jember dan PDRB Propinsi Jawa Timur Tahun 2005-2009 atas dasar harga berlaku dan atas dasar harga konstan yang bersumber dari dokumentasi BPS. Selain itu juga digunakan data lainnya yang terkait yang berasal dari berbagai instansi. Analisis data dilakukan secara deskriptif kualitatif dengan menggunakan tabel-tabel

Metode Analisis

Analisis LQ

Perhitungan LQ menggunakan rumus sebagai berikut (TariganRobinson, 2005) :

$$
L Q=\frac{\frac{S_{i}}{S}}{\frac{N i}{N}}
$$

Dimana :

LQ : Nilai Location Quotient

$\mathrm{S}_{\mathrm{i}} \quad$ : PDRB Sektor i di Kabupaten Jember

$\mathrm{S} \quad$ : PDRB total di Kabupaten Jember

$\mathrm{N}_{\mathrm{i}}$ : PDRB Sektor i di Provinsi Jawa Timur

$\mathrm{N}$ : PDRB total di Provinsi Jawa Timur

\section{Analisis Shift Share}

Rumus yang digunakan (Tarigan

Robinson, 2005) :

$\Delta \mathrm{E}_{\mathrm{r}}=\mathrm{E}_{\mathrm{r}, \mathrm{t}}-\mathrm{E}_{\mathrm{r}, \mathrm{t}-\mathrm{n}}$

$\mathrm{N}_{\mathrm{sr}, \mathrm{i}, \mathrm{t}}=\mathrm{E}_{\mathrm{r}, \mathrm{I}, \mathrm{t}-\mathrm{n}}\left(\mathrm{EN}_{\mathrm{t}, \mathrm{t}} / \mathrm{EN}_{, \mathrm{t}-\mathrm{n}}\right)-\mathrm{E}_{\mathrm{r}, \mathrm{i}, \mathrm{t}-\mathrm{n}}$

$(\mathrm{P}+\mathrm{D})_{\mathrm{r}, \mathrm{i}, \mathrm{t}}=\mathrm{E} \mathrm{r,t}-(\mathrm{E} \mathrm{N}, \mathrm{t} / \mathrm{EN}, \mathrm{t}-\mathrm{n}) \mathrm{E}_{\mathrm{r}, \mathrm{t}-\mathrm{n}}$ $=(\Delta \mathrm{E}-\mathrm{N})_{\mathrm{r}}$

$\mathrm{P}_{\mathrm{r}, \mathrm{i}, \mathrm{t}}=\left\{\left(\mathrm{EN}_{\mathrm{i}, \mathrm{t}} / \mathrm{EN}_{\mathrm{i}, \mathrm{t}-\mathrm{n}}\right)-\left(\mathrm{EN}_{, \mathrm{t}} / \mathrm{EN}_{\mathrm{t}-\mathrm{n} \mathrm{n}}\right) \mathrm{E}_{\mathrm{r}, \mathrm{i}, \mathrm{t}-\mathrm{n}}\right\}$

$\mathrm{D}_{\mathrm{r}, \mathrm{i}, \mathrm{t}}=\left\{\left(\mathrm{E}_{\mathrm{r}, \mathrm{i}, \mathrm{t}}-\left(\mathrm{EN}_{, \mathrm{i}, \mathrm{t}} / \mathrm{EN}_{\mathrm{i}, \mathrm{i}, \mathrm{n}}\right) \mathrm{E} \mathrm{r,i,t-n}\right\}\right.$

Dimana :

$\Delta \mathrm{Er}=$ Komponen Pertumbuhan PDRB Kabupaten Jember

$\mathrm{Nr}=$ Komponen national share di Kabupaten Jember

$(\mathrm{P}+\mathrm{D})_{\mathrm{r}, \mathrm{i}, \mathrm{t}}=$ Komponen net Shift di Kabupaten Jember

Pr =Komponen proportional shift di Kabupaten Jember

Dr =Komponen differential Shift di Kabupaten Jember

$\mathrm{r} \quad=$ PDRB total Kabupaten Jember

$\mathrm{N}=$ PDRB total Provinsi Jawa Timur

$\mathrm{i}=$ Sektor

$\mathrm{t}-\mathrm{n}=$ Tahun Awal

$\mathrm{t}=$ Tahun Akhir

$\mathrm{E}=$ Banyaknya PDRB

\section{ANALISIS HASIL DAN PEMBAHASAN \\ Deskripsi Objek Penelitian \\ Kondisi WilayahKabupaten Jember}

Kabupaten Jember memiliki wilayah seluas 3.293.34 $\mathrm{Km}^{2}$ atau 329.333 hektar, yang terbagi menjadi 31 wilayah kecamatan, yaitu Kecamatan Balung, Ambulu, Wuluhan, Puger, Gumukmas, Kencong, Kaliwates, Tempurejo, Sumbersari, Ledokombo, Bangsalsari, Mumbulsari, Umbulsari, Mayang, Pakusari, Sukowono, Jenggawah, Kalisat, Arjasa, Jelbuk, Tanggul, Rambipuji, Silo, Patrang, Sumberjambe, Sukorambi, Sumberbaru, Panti.

\section{Letak Geografi}

Kabupaten Jember merupakan salah satu kabupaten di Propinsi Jawa Timur, yang terletak di wilayah bagian timur dan masuk dalam wilayah Karesidenan Besuki. Posisi koordinatnya adalah 7059'6" sampai 8033'56" Lintang Selatan dan 6027'6" sampai 7014'33" Bujur Timur.

Batas-batas administratif Kabupaten Jember adalah sebagai berikut:

- Utara : Kabupaten Bondowoso dan Probolinggo

- Timur : Kabupaten Banyuwangi

- Selatan: Samudra Indonesia

- Barat : Kabupaten Bondowoso dan Iklim probolinggo

Curah hujan bulanan yang terjadi di Wilayah Kabupaten Jember pada tahun 2009 adalah berkisar antara $48,6 \mathrm{~mm}^{3}$ sampai dengan $257,8 \mathrm{~mm}^{3}$, Rata-rata curah hujan per hari tertinggi terjadi pada bulan November di Kecamatan Wuluhan, stasiun pengukur Tanjungrejo yang mencapai $47,9 \mathrm{~mm}^{3}$.

Musim kemarau terjadi pada bulan JuniSeptember, hal ini berkaitan dengan arus angin yang berasal dari arah Australia dan tidak mengandung uap air. Musim penghujan berlangsung pada bulan Januari sampai dengan bulan Mei dan bulan Oktober sampai dengan bulan Desember.

Bentuk wilayah (morfologi) Kabupaten Jember terbagi atas dataran landai/rendah berbukit sampai bergunung. Dataran rendah antara lain meliputi kecamatan-kecamatan Kencong, Gumukmas, Puger, Wuluhan, Ambulu, Tempurejo, Mayang, Mumbulsari, Jenggawah, Ajung, Rambipuji, Balung, Umbulsari, Semboro, Jombang, Bangsalsari, Pakusari, Kaliwates, Sumbersari. Wilayah berbukit sampai bergunung antara lain meliputi wilayah kecamatan-kecamatan Silo, Sumberbaru, Tanggul, Bangsal, Panti, Sukorambi, Arjasa, Kalisat, Ledokombo, Sumberjambe, Sukowono, Jelbuk dan Patrang. 
Tinggi tempat wilayah kabupaten Jember terletak antara 0 - >1.000 meter di atas permukaan laut (m dpl). Berdasarkan ketinggian tempat tersebut, maka wilayah Kabupaten Jember dapat diklasifikasikan berdasarkan Wilayah Tanah Usaha (WTU) sebagai berikut :

1. Ketinggian $0-25 \mathrm{~m}$ dpl meliputi luas wilayah $591,20 \mathrm{Km}^{2} \quad(17,95 \%$ dari luas wilayah Kabupaten Jember dan meliputi Kecamatan Kencong, Gumukmas, Puger, Wuluhan, Ambulu, Tempurejo, Balung, Umbulsari, Semboro, Jombang, Sumberbaru, Tanggul, Sumbersari;

2. Ketinggian $25-100 \mathrm{~m} \mathrm{dpl} \mathrm{meliputi} \mathrm{luas}$ wilayah $681,68 \mathrm{Km}^{2} \quad(20,70 \%$ dari luas wilayah Kabupaten Jember) dan meliputi Kecamatan Gumukmas, Puger, Wuluhan, Ambulu, Tempurejo, Silo, Mayang, Mumbulsari, Jenggawah, Ajung, Rambipuji, Balung, Umbulsari, Semboro, Sumberbaru, Tanggul, Bangsalsari, Panti, Sukorambi, Patrang

3. Ketinggian $100-500 \mathrm{~m} \mathrm{dpl} \mathrm{meliputi} \mathrm{luas}$ wilayah $1.243,08 \mathrm{Km}^{2} \quad(37,75 \%$ dari luas wilayah Kabupaten Jember) dan meliputi Kecamatan Gumukmas, Puger, Wuluhan, Ambulu, Tempurejo, Silo, Mayang, Mumbulsari, Jenggawah, Semboro, Sumberbaru, Tanggul, Bangsalsari, Panti, Sukorambi, Arjasa, Pakusari, Kalisat, Ledokombo, Sumberjambe, Sukowono, Jelbuk, Kaliwates, Sumbersari, Patrang;

4. Ketinggian $500-1.000 \mathrm{~m} \mathrm{dpl}$ meliputi luas wilayah $520,43 \mathrm{Km}^{2} \quad(15,80 \%$ dari luas wilayah Kabupaten Jember) dan meliputi Kecamatan Gumukmas, Tempurejo, Silo, Mayang, Mumbulsari, Sumberbaru, Tanggul, Bangsalsari, Panti, Sukorambi, Arjasa, Ledokombo, Sumberjambe, Jelbuk, Kaliwates, Sumbersari;

5. Ketinggian $>1.000 \mathrm{~m} \mathrm{dpl}$ meliputi luas wilayah 225,62 $\mathrm{Km}^{2}$ (7,80 \% dari luas wilayah Kabupaten Jember) dan meliputi Kecamatan Tempurejo, Silo, Tanggul,Bangsalsari, Panti, Sukorambi, Arjasa, Ledokombo, Sumberjambe, Jelbuk.

\section{Penggunaan Lahan}

Untuk mengetahui jenis tanah yang ada di

Kabupaten Jember telah dilakukan pengamatanlapangan dan pemboran dangkal dengan bor tangan. Berdasarkan hasil analisa jenis tanah, peta tanah tinjau skala 1:125 000 (Bappeda Kabupaten Jember, 1986), jenis tanah yang ada secara garis besar adalah termasuk jenis Aluvial.

Pola penggunaan tanah di wilayah Kabupaten Jember terdiri dari berbagai jenis penggunaan tanah. Berdasarkan penggunaan lahan yang ada menunjukkan bahwa mayoritas penggunaan lahan berturut-turut adalah hutan sebesar 36,75 persen, sawah sebesar 26,32 persen, tegal atau lading sebesar 13,29 persen dan perkebunan sebesar 10,50 persen.

Secara umum tanah ini mempunyai sifat fisik yang cukup baik, dan sifat kimia yang sedang sampai baik.Oleh karena itu, produktivitas tanahnya adalah sedang sampai tinggi.Jenis Tanah aluvial hanya meliputi lahan yang dipengaruhi oleh aktivitas sungai/mengalami banjir, sehingga dapat dianggap masih muda dan belum ada diferensiasi horison. Suatu hal yang mencirikan pada pembentukan aluvial adalah bahwa sebagian terbesar bahan kasar akan diendapkan tidak jauh dari sumbernya.

Di wilayah Kabupaten Jember terdapat 16 Daerah Aliran Sungai (DAS)yang masingmasing DAS terdiri dari beberapa aliran sungai yang kemudian mengaliri lahan-lahan di sekitarnya. Sungai yang paling besar adalah sungai Bedadung yang melintasi ibu kota sepanjang $46.875 \mathrm{~m}$ dan mampu mengairi kawasan seluas 93.040 hektar.

\section{Struktur Perekonomian}

Salah satu pos pendapatan daerah untuk membiayai belanjanya adalah dari Pendapatan Asli Daerah (PAD).Jumlah PAD Kabupaten Jember pada tahun 2007 adalah sebesar Rp. 1.114.309.658.324. PAD terbesar dari pajak dan retribusi daerah. Sejak diberlakukannya otonomi daerah pada bagian dana pertimbangan pos Dana Alokasi Umum (DAU). DAU Kabupaten Jember pada tahun 2008 sebesar Rp. 861.126.000.000.

Sektor ekonomi yang mengalami pertumbuhan ekonomi sangat menyolok terjadi pada sektor industri pengolahan, perdagangan dan restoran serta keuangan, persewaan dan jasa perusahaan. Besar pertumbuhan ekonomi pada ketiga sektor tersebut disebabkan beberapa hal antara lain :

1.Sektor keuangan, persewaan dan jasa perusahaan: peningkatan pada sektor ini disebabkan semakin pulihnya fungsi intermediasi bank.

2.Sektor industri pengolahan, perdagangan dan restoran, peningkatan pada sektor ini disebabkan overhead yang dilakukan oleh pemerintah dalam memacu perekonomian Kabupaten Jember

\section{Potensi pertanian}

Potensi pertanian di Kabupaten Jember dikelompokkan secara terbatas pada sub sektor tanaman pangan, Holtikultura, Perkebunan dan perternakan. Pendekatan yang dilakukan dalam melihat potensi pertanian di Kabupaten Jember terbatas pada luas panen, produksi dan produktivitas. Jenis komoditas yang diusahakan dapat dikelompokkan, yaitu: 
1. Tanaman Pangan meliputi komoditas padi, jagung, ubi kayu, ubi jalar, kacang tanah, kedelai.

2. Tanaman hortikultura meliputi komoditas tanaman sayuran (bawang merah, kobis, kembang kol, sawi, kacang panjang, cabe besar, cabe kecil, tomat, terong, buncis, ketimun, labu siam, kakung, bayam) dan tanaman buah-buahan (alpukat, duku/langsat, jambu air, jambu biji, jeruk besar, jeruk siam, mangga, rambutan, manggis, sirsat, sukun, durian, sawo, pepaya, pisang, nanas, salak, nangka, belimbing, melon, semangka, melinjo, petai, markisa ).

3. Tanaman perkebunan meliputi komoditas kelapa, kopi, cengkeh, kapuk rundu, pinang, jambu mete, tembakau, lada, panili.

4. Komoditas peternakan, meliputi sapi potong, sapi perah, kuda, kerbau, kambing, domba, itik, ayam kampung, ayam ras petelur dan ayam ras pedaging.

5. Komoditas perikanan meliputi kelompok penangkapan dan kelompok budidaya. Kelompok penangkapan meliputi perikanan laut dan perikanan umum. Kelompok budidaya meliputi tambak, kolam, mina padi, KPI dan keramba.

ANALISIS HASIL

Perkembangan PDRB Kabupaten Jember Selama 5 Tahun (Tahun 2005-2009) pada Masing-masing Sektor

Data Produk Domestik Regional Bruto (PDRB) merupakan salah satu data statistik yang digunakan untuk menilai kinerja ekonomi secara makro di suatu wilayah dalam periode waktu tertentu. Dua kriteria kinerja ekonomi makro yang terkait dengan PDRB ialah laju pertumbuhan ekonomi dan kontribusi sektor-sektor ekonomi. Untuk melihat pergeseran kontribusi sektor ekonomi dapat dilakukan dengan mengkaji PDRB atas dasar harga berlaku.

Pendekatan produksi yaitu menghitung nilai tambah barang dan jasa yang dihasilkan seluruh unit produksi di suatu wilayah dalam periode waktu tertentu. Unit-unit produksi tersebut dikelompokkan menjadi sembilan lapangan usaha (sektor ekonomi) yaitu (1) pertanian; (2) pertambangan dan penggalian; (3) industripengolahan; (4) listrik, gas dan air bersih; (5) bangunan/konstruksi; (6) perdagangan, hotel dan restoran; (7) pengangkutan dan komunikasi; (8) keuangan, persewaan dan jasa perusahaan; dan (9) jasa-jasa. Pada setiap sektor ekonomi tersebut selanjutnya dirinci lagi menjadi sub-sub sektor.

Pendekatan Pendapatan yaitu menghitung PDRB dengan menjumlahkan balas jasa yang diterima oleh faktor-faktor produksi yang ikut serta dalam proses produksi di suatu wilayah dalam periode waktu tertentu. Balas jasa faktor produksi yang dimaksud adalah (1) upah dan gaji; (2) sewa tanah; (3) bunga modal dan keuntungan. Semua penghitungan sebelum dipotong pajak penghasilan dan pajak langsung lainnya.

Pendekatan Pengeluaran yaitu menghitung PDRB sebagai penjumlahan semua komponen permintaan akhir yang terdiri dari (1) pengeluaran konsumsi rumah tangga dan lembaga swasta nirlaba; (2) pengeluaran konsumsi pemerintah; (3) pembentukan modal tetap domestik bruto; (4) perubahan inventori; dan (5) ekspor neto (nilai ekspor dikurangi nilai impor).

Perkembangan kondisi sosial ekonomi di Kabupaten Jember dapat dilihat melalui beberapa indikator Makro Ekonomi.Rata-rata pertumbuhan Product Domestic Regional Bruto (PDRB). Pada tahun 2005-2009 PDRB atas dasar harga berlaku secara berurutan Tahun 2005 sebesar Rp. 12.460.346,18, Tahun 2006 sebesar Rp. 14.368.695,65, Tahun 2007 sebesar Rp. 16.306.131,96, Tahun 2008 sebesar Rp. 19.210.151,44, dan Tahun 2009 sebesar Rp. 21.412.572,63.

Secara agregat nilai PDRB menurut lapangan usaha Kabupaten Jember Kurun waktu Tahun 2005-2009 atas harga berlaku menunjukkan perkembangan meningkat dari tahun ke tahun, begitu juga dengan nilai PDRB atas harga konstan. Hal ini menunjukkan bahawa kinerja perkembangan perekomian kondisi sosial ekonomi makro pertumbuhan rata-rata PDRB yang terjadi kurun waktu 5 tahun yaitu antara tahun 2005-2009 mengalami kenaikan yang signifikan (mengalami perkembangan yang positif).

Pertumbuhan ekonomi di Kabupaten Jember, setiap tahunnya antara Tahun 2005-2009 menunjukkan peningkatan. Penyumbang angka pertumbuhan ekonomi terbesar,di sumbang dari sector pertanian. Akan tetapi, pertumbuhan sektor pertanian, terus mengalami penurunan. Berdasarkan data dari Badan Pusat Statistik (BPS) Kabupaten Jember, di Tahun 2008, sumbangan dari sektor pertanian sebesar 40,80\%, Tahun 2009 mulai mengalami penurunan produktivitas dan menyumbang hanya sebesar $40,67 \%$, turunnya pertumbuhan produktivitas sektor pertanian, bisa disebabkan beberapa faktor. Diantaranya, faktor anomali cuaca, ahli fungsi lahan, organisme pengganggu tanaman, seperti hama, dan penyebab yang temporer terjadi, seperti bencana. Dia mencontohkan, tahun lalu, kondisi cuaca di Kabupaten Jember, terbilang tidak stabil. Karena seringnya hujan dan terjadinya pendangkalan di sejumlah daerah, musibah banjir sering terjadi, sehingga menyebabkan para petani mengalami 
gagal panen.Sementara untuk alihfungsi lahan, merupakan faktor yang selalu terjadi secara terusmenerus.Saat ini, banyak lahan pertanian yang dijadikan sebagai lokasi perumahan, bangunan industrialisasi, sehingga terjadi pengurangan luasan lahan pertanian, yang menyebabkan produktivitas pertanian menjadi turun.Sementara itu, pertumbuhan penduduk terus mengalami peningkatanpertumbuhan ekonomi di Kabupaten Jember dapat terus menanjak, dengan dibantu oleh komoditas lainnya, yang saat ini pertumbuhannya terus meningkat, seperti sektor perdagangan, perhotelan dan restoran.

\section{- Pertumbuhan Ekonomi Kabupaten Jember Tahun 2005-2009}

Pertumbuhan ekonomi merupakan salah satu ukuran dari hasil pembangunan yang dilaksanakan, khususnya bidang ekonomi.Pertumbuhantersebut merupakan gambaran tingkat perkembangan ekonomi terjadi.Pertumbuhan ekonomi secara rinci dari tahun ke tahun, disajikan melalui Product Domestic Bruto (PDB) atas dasar harga konstan menurut lapangan usaha secara berkala.Jikaterjadi pertumbuhan positif, hal ini menunjukkan adanya peningkatan perekonomian dibandingkan dengan tahun yang lalu.Sebaliknya apabila menunjukkan negatif, hal ini menunjukkan terjadinyapenurunan perekonomian dibandingkan dengan tahun lalu. Perkembangan PDRBKabupaten Jember Tahun 2005 - 2009 atas dasar harga konstan tahun 2000 disajikan pada Tabel Untuk menghitung laju pertumbuhan ekonomi, digunakan rumus sebagai berikut:

Tabel Pertumbuhan dan Laju Pertumbuhan Ekonomi Kabupaten Jember Tahun 2005-2009

\begin{tabular}{ccc}
\hline TAHUN & PDRB & Laju Pertumbuhan \% \\
\hline 2005 & $8,236,276.67$ & 5.31 \\
2006 & $8,705,996.37$ & 5.70 \\
2007 & $9,226,767.89$ & 5.98 \\
2008 & $9,783,828.13$ & 6.04 \\
2009 & $10,326,735.61$ & 5.55 \\
\hline
\end{tabular}

Sumber : BPS Kabupaten Jember 2010

\section{Sektor-Sektor Basis dalam Perekonomian Kabupaten Jember Tahun 2005-2009}

Dalam perekonomian regional terdapat kegiatan-kegiatan basis dan kegiatan- kegiatan bukan basis.Menurut Glasson (1990) kegiatankegiatan Basis (Basic activities) adalah kegiatan mengekspor atau memasarkan barang dan jasa keluar batas perekonomian masyarakatnya atau kepada orang yang datang dari luar perbatasan perekonomian masyarakat yang bersangkutan. Sedangkan kegiatan bukan basis (Non basic activities ) adalah kegiatan menyediakan barang yang dibutuhkan oleh orang yang bertempat tinggal didalam batas perekonomian masyarakat yang bersangkutan. Bertambah banyaknya kegiatan basis dalam suatu daerah akan menambah arus pendapatan kedalam daerah yang bersangkutan, menambah permintaan barang dan jasa sehingga akan menimbulkan kenaikan volume kegiatan. Sebaliknya berkurangnya kegiatan basis akan mengurangi pendapatan suatu daerah dan turunnya permintaan terhadap barang dan jasa dan akan menurunkan volume kegiatan (Richardson, 1977).

Metode LocationQuotient (LQ) adalah salah satu teknik pengukuran yang paling terkenal dari model basis ekonomi untuk menentukan sektor basis atau non basis (Prasetyo, 2001: 41-53;
Lincolyn, 1997: 290). Seperti diketahui bahwa sektor basis merupakan sektor-sektor yang mempunyai nilai LQ > 1 sedang sektor non basis adalah sektor-sektor yang mempunyai nilai LQ < 1. Untuk mengetahui sektor potensial di suatu daerah, alat analisis yang digunakan adalah dengan melihat nilai Location Quotients (LQ), yang merupakan perbandingan kontribusi masingmasing sektor terhadap pembentukan PDRB.

Denganmempertimbangkanperkembangan PDRB Kabupaten Jember Tahun 2005-2009 perhitungan sektor-sektor basis perekonomian yang terjadi di Kabupaten Jember dilakukan dengan membandingkan PDRB Kabupaten Jember Tahun 2005-2209 dengan PDRB Provinsi Jawa Timur tahun 2005-2009. Hasil perhitungan dengan metode LQ menunjukkan bahwa sejak tahun tahun 2005 - 2009 mengalami perubahan yang tidak berarti. Sektor basis di setiap lapangan usaha cenderung tetap, tidak banyak sektor yang mengalami perubahan dari sektor bukan basis ke sektor basis demikian pula sebaliknya. Hal ini menandakan bahwa pembangunan di Kabupaten Jember Provinsi Jawa Timur mulai tahun 2005 2009 tidak banyak mengalami perubahan.

Secara lengkap hasil analisis LQ untuk masing-masing sektor selama 5 tahun sejak tahun 2005 - 2009 dapat dijelaskan sebagai berikut : 
Jurnal Ilmiah INOVASI, Vol.14 No.1 Hal. 82-93, Januari-April 2014, ISSN 1411-5549

Tabel Hasil Perhitungan LQ Tiap Sektor Kabupaten Jember 2005-2009

\begin{tabular}{|c|c|c|c|c|c|c|}
\hline \multirow{2}{*}{ Lapangan Usaha } & \multicolumn{5}{|c|}{ Tahun } & \multirow{2}{*}{$\begin{array}{c}\text { Rata-rata } \\
\text { LQ }\end{array}$} \\
\hline & 2005 & 2006 & 2007 & 2008 & 2009 & \\
\hline Pertanian & 2.59 & 2.61 & 2.67 & 2.67 & 2.68 & 2.644 \\
\hline Pertambangan dan Penggalian & 1.95 & 1.80 & 1.77 & 1.72 & 1.71 & 1.79 \\
\hline Industri Pengolahan & 0.25 & 0.25 & 0.26 & 0.26 & 0.26 & 0.26 \\
\hline Listrik Dan Air Bersih & 0.46 & 0.59 & 0.56 & 0.58 & 0.58 & 0.55 \\
\hline Bangunan & 0.89 & 0.81 & 0.83 & 0.85 & 0.83 & 0.84 \\
\hline $\begin{array}{l}\text { Perdagangan, Hotel Dan } \\
\text { Restoran }\end{array}$ & 0.71 & 0.71 & 0.69 & 0.69 & 0.70 & 0.70 \\
\hline $\begin{array}{l}\text { Pengangkutan Dan } \\
\text { Komunikasi }\end{array}$ & 0.81 & 0.82 & 0.82 & 0.84 & 0.81 & 0.82 \\
\hline Keuangan, Persewaan & & & & & & \\
\hline $\begin{array}{l}\text { Bangunan Dan Jasa } \\
\text { Perusahaan }\end{array}$ & 1.37 & 1.35 & 1.34 & 1.32 & 1.32 & 1.34 \\
\hline Jasa - Jasa & 1.22 & 1.14 & 1.14 & 1.14 & 1.11 & 1.15 \\
\hline
\end{tabular}

hasil analisis LQ pada sektor perekonomian (lapangan usaha) tahun 2005-2009, hasil Perhitungan dengan menggunakan PDRB menghasilkan LQ dengan angka hasil yang sedikit berbeda namun dengan urutan peringkat sebagai berikut :

LQ > 1 merupakan sektor basis/unggulan untuk Kabupaten Jember kurun waktu tahun 2005-2009 adalah :

1. Pertanian

2. Pertambangan dan penggalian

3. Keuangan, Persewaan Bangunan Dan Jasa Perusahaan

4. Jasa-jasa

LQ $<1$ merupakan sektor non basis/unggulan untuk Kabupaten Jember kurun waktu tahun 20052009 adalah :

1. Bangunan

2. Pengangkutan Dan Komunikasi

3. Perdagangan, Hotel Dan Restoran

4. Listrik Dan Air Bersih

5. Industri Pengolahan

Secara umum hasil perhitungan LQ kurun waktu tahun 2005-2009 sektor-sektor basis dalam perekonomian Kabupaten Jember tidak mengalami perubahan yang berarti dalam artian kurun waktu 5 tahun antara tahun 2005-2009 perekonomian menurut lapangan usaha secara struktur tingkatan dan urutannya sumbangan terhadap perekonomian dari sembilan sektor lapangan usaha di Kabupaten Jember yang meliputi pertanian, pertambangan dan penggalian, keuangan, persewaan bangunan dan jasa perusahaan, jasa-jasa, bangunan, pengangkutan dan komunikasi, perdagangan, hotel dan restoran, listrik dan air bersih, industri pengolahan tidak mengalami perubahan.

Struktur Perekonomian Atau Peranan Sektor Ekonomi Potensial Sebagai Penunjang Pertumbuhan Ekonomi Di Kabupaten Jember Tahun 2005-2009 


\begin{tabular}{crrrrc}
\hline \multirow{2}{*}{ Sektor } & \multicolumn{2}{c}{ PDRB (Jutaan Rp) } & \multicolumn{2}{c}{ Kontribusi Sektoral Terhadap } & PERING \\
& $\mathbf{2 0 0 5}$ & \multicolumn{1}{c}{ PDRB } & \multicolumn{1}{c}{ KAT } \\
\hline $\mathbf{1}$ & $5,570,799.50$ & $9,362,652.83$ & $3,791,853.33$ & 42.36 & I \\
$\mathbf{2}$ & $487,871.93$ & $814,165.10$ & $326,293.17$ & 3.64 & VII \\
$\mathbf{3}$ & $924,718.99$ & $1,583,355.19$ & $658,636.20$ & 7.36 & IV \\
$\mathbf{4}$ & $108,497.17$ & $193,419.05$ & $84,921.88$ & 0.95 & IX \\
$\mathbf{5}$ & $398,587.29$ & $711,994.46$ & $313,407.17$ & 3.50 & VIII \\
$\mathbf{6}$ & $2,410,822.29$ & $4,283,639.97$ & $1,872,817.68$ & 20.92 & II \\
$\mathbf{7}$ & $557,667.82$ & $953,423.22$ & $395,755.40$ & 4.42 & VI \\
$\mathbf{8}$ & $775,081.16$ & $1,363,021.11$ & $587,939.95$ & 6.57 & V \\
$\mathbf{9}$ & $1,226,300.03$ & $2,146,901.69$ & $920,601.66$ & 10.28 & III \\
\hline PDRB & $\mathbf{1 2 , 4 6 0 , 3 4 6 . 1 8}$ & $\mathbf{2 1 , 4 1 2 , 5 7 2 . 6 2}$ & $\mathbf{8 , 9 5 2 , 2 2 6 . 4 4}$ & $\mathbf{1 0 0 . 0 0}$ & \\
\hline
\end{tabular}

Sumber : Data BPS Kabupaten Jember diolah

Keterangan :

Sektor :

1. Pertanian

2. Pertambangan dan Penggalian

3. Industri Pengolahan

4. Listrik Dan Air Bersih

5. Bangunan

6. Perdagangan, Hotel Dan Restoran

7. Pengangkutan Dan Komunikasi

8. Keuangan, Persewaan Bangunan Dan Jasa Perusahaan

9. Jasa - Jasa

Denganmempertimbangkan erkembangan PDRB Kabupaten Jember Tahun 2005-2009 perhitungan sektor-sektor basis perekonomian yang terjadi di Kabupaten Jember dilakukan dengan membandingkan PDRB Kabupaten Jember Tahun 2005-2209 dengan PDRB Provinsi Jawa Timur tahun 2005-2009. Hasil perhitungan dengan metode LQ menunjukkan bahwa sejak tahun tahun 2005 - 2009 mengalami perubahan yang tidak berarti. Sektor basis di setiap lapangan usaha cenderung tetap, tidak banyak sektor yang mengalami perubahan dari sektor bukan basis ke sektor basis demikian pula sebaliknya. Hal ini menandakan bahwa pembangunan di Kabupaten Jember Provinsi Jawa Timur mulai tahun 2005 2009 tidak banyak mengalami perubahan.

Kesatu hasil perhitungan shift share untuk kontribusi masing-masing sektor di Kabupaten Jember tidaklah sama. Pertama Kondisi ini memperlihatkan selama kurun waktu tahun 20052009 struktur perekonomian masih dominan di sektor pertanian dibandingkan dengan sektorsektor yang lain. Kontribusi sektor pertanian pada tahun 2005 sebesar $44.71 \%$ terhadap PDRB dan pada tahun 2009 kontribusi sektor pertanian mengalami penurunan menjadi sebesar $43.73 \%$ mengalami penurunan hanya sekitar $09.8 \%$, untuk laju pertumbuhan secara agregate di sektor pertanian kurun waktu tahun 2005-2009 sebesar $68.07 \%$ dan pertumbuhan di sektor pertanian secara nominal sebesar 3,791,853.33 juta

. Kedua selanjutnya strukutur perekonomian terhadap PDRB adalah sektor perdagangan, hotel, dan restauran pada tahun 2005 memiliki kontribusi terhadap PDRB di Kabupaten Jember sebesar $19.35 \%$ dan selanjutnya pada tahun 2009 kontribusi pada sektor ini menunjukkan adanya kenaikan sebesar $0.66 \%$ menjadi $20.01 \%$ untuk laju pertumbuhan secara agregate di sektor perdagangan, hotel, dan restauran kurun waktu tahun 2005-2009 sebesar $77.68 \%$ dan pertumbuhan secara nominal sebesar 1,872,817.68 juta.

Ke tiga adalah sekor jasa-jasa pada tahun 2005 memiliki kontribusi terhadap PDRB di Kabupaten Jember sebesar $9.84 \%$ dan selanjutnya pada tahun 2009 kontribusi pada sektor ini menunjukkan adanya kenaikan sebesar $0.19 \%$ menjadi $10.03 \%$ untuk laju pertumbuhan secara agregate di sektor jasa-jasa kurun waktu tahun 2005-2009 sebesar $75.07 \%$ dan pertumbuhan secara nominal sebesar 920,601.66 juta.

Ke empat adalah sektor industri pengolahan 
pada tahun 2005 memiliki kontribusi terhadap PDRB di Kabupaten Jember sebesar 7,42\%\% dan selanjutnya pada tahun 2009 kontribusi pada sektor ini menunjukkan adanya penurunan sebesar $0.03 \%$ menjadi $7,39 \%$ untuk laju pertumbuhan secara agregate di sektor industri pengolahan kurun waktu tahun 2005-2009 sebesar 71,23\% dan pertumbuhan secara nominal sebesar $658,636.20$ juta.

Ke lima adalah sektor keuangan, persewaan bangunan dan jasa perusahaan pada tahun 2005 memiliki kontribusi terhadap PDRB di Kabupaten Jember sebesar $6,22 \% \%$.Tinggi rendahnya laju pertumbuhan tersebut lebih disebabkan adanya fluktuasi laju pertumbuhan beberapa sektor ekonomi, utamanya sektor pertanian yang merupakan sektor dominan yang telah mengalami fluktuasi cukup tajam. Rendahnya pertumbuhan ekonomi Kabupaten Jember mencapai sebesar 5,55\% pada Tahun 2009 sebagai akibat juga rendahnya laju pertumbuhan sektor pertanian yang mencapai $5,24 \%$ yang juga merupakan titik terendah pertumbuhan sector pertanian pada tahun
2009.

Sektor-Sektor Basis dalam Perekonomian Kabupaten Jember Tahun 2005-2009

Denganmempertimbangkan erkembangan PDRB Kabupaten Jember Tahun 2005-2009 perhitungan sektor-sektor basis perekonomian yang terjadi di Kabupaten Jember dilakukan dengan membandingkan PDRB Kabupaten Jember Tahun 2005-2209 dengan PDRB Provinsi Jawa Timur tahun 2005-2009. Hasil perhitungan dengan metode LQ menunjukkan bahwa sejak tahun tahun 2005 - 2009 mengalami perubahan yang tidak berarti. Sektor basis di setiap lapangan usaha cenderung tetap, tidak banyak sektor yang mengalami perubahan dari sektor bukan basis ke sektor basis demikian pula sebaliknya. Hal ini menandakan bahwa pembangunan di Kabupaten Jember Provinsi Jawa Timur mulai tahun 2005 2009 tidak banyak mengalami perubahan.

Secara lengkap hasil analisis LQ untuk masingmasing sektor selama 5 tahun sejak tahun $2005-$ 2009 dapat dijelaskan sebagai berikut :

Tabel Hasil Perhitungan LQ Tiap Sektor Kabupaten Jember 2005-2009

\begin{tabular}{|c|c|c|c|c|c|c|}
\hline \multirow{2}{*}{ Lapangan Usaha } & \multicolumn{5}{|c|}{ Tahun } & \multirow{2}{*}{$\begin{array}{c}\text { Rata-rata } \\
\text { LQ }\end{array}$} \\
\hline & 2005 & 2006 & 2007 & 2008 & 2009 & \\
\hline Pertanian & 2.59 & 2.61 & 2.67 & 2.67 & 2.68 & 2.644 \\
\hline $\begin{array}{l}\text { Pertambangan dan } \\
\text { Penggalian }\end{array}$ & 1.95 & 1.80 & 1.77 & 1.72 & 1.71 & 1.79 \\
\hline Industri Pengolahan & 0.25 & 0.25 & 0.26 & 0.26 & 0.26 & 0.26 \\
\hline Listrik Dan Air Bersih & 0.46 & 0.59 & 0.56 & 0.58 & 0.58 & 0.55 \\
\hline Bangunan & 0.89 & 0.81 & 0.83 & 0.85 & 0.83 & 0.84 \\
\hline $\begin{array}{l}\text { Perdagangan, Hotel Dan } \\
\text { Restoran }\end{array}$ & 0.71 & 0.71 & 0.69 & 0.69 & 0.70 & 0.70 \\
\hline $\begin{array}{l}\text { Pengangkutan Dan } \\
\text { Komunikasi } \\
\text { Keuangan, Persewaan }\end{array}$ & 0.81 & 0.82 & 0.82 & 0.84 & 0.81 & 0.82 \\
\hline $\begin{array}{l}\text { Bangunan Dan Jasa } \\
\text { Perusahaan }\end{array}$ & 1.37 & 1.35 & 1.34 & 1.32 & 1.32 & 1.34 \\
\hline Jasa - Jasa & 1.22 & 1.14 & 1.14 & 1.14 & 1.11 & 1.15 \\
\hline
\end{tabular}

Sumber : Data Sekunder Diolah

Pada tabel menggambarkan bahwa hasil analisis LQ pada sektor perekonomian (lapangan usaha)

Hal ini menunjukkan bahwa sektor pertanian masih merupakan sektor yang diunggulkan untuk di wilayah Kabupaten Jember karena 4 (empat) dari Sembilan sektor lapangan usaha yang ada di Kabupaten Jember kurun waktu tahun 2005-2009 sektor pertanian merupakan sektor basis yang memiliki nilai LQ paling tinggi dengan rata-rata sebesar 2,64 sehingga menunjukkan LQ > 1 dan selama periode tahun 2005-2009 sektor pertanian mempunyai kontribusi yang besar terhadap pembentukan PDRB. Dengan kata lain sektor pertanian mempunyai kemampuan terhadap peningkatan perekonomian baik di kabupaten maupun di tingkat Propinsi. Adapun dari ke Sembilan sector lapangan usaha yang termasuk sector non basis adalah bangunan, pengangkutan dan komunikasi, perdagangan, hotel dan restoran, listrik dan air bersih, dan industri pengolahan dimana memiliki hasil perhitungan LQ $<1$.

Struktur Perekonomian Atau Peranan Sektor Ekonomi Potensial Sebagai Penunjang Pertumbuhan Ekonomi Di Kabupaten Jember Tahun 2005-2009 
Hasil perhitungan shift share untuk kontribusi masing-masing sektor di Kabupaten Jember tidaklah sama.

Pertama Kondisi ini memperlihatkan selama kurun waktu tahun 2005-2009 struktur perekonomian masih dominan di sektor pertanian dibandingkan dengan sektor-sektor yang lain. Kontribusi sektor pertanian pada tahun 2005 sebesar $44.71 \%$ terhadap PDRB dan pada tahun 2009 kontribusi sektor pertanian mengalami penurunan menjadi sebesar $43.73 \%$ mengalami penurunan hanya sekitar $09.8 \%$, untuk laju pertumbuhan secara agregate di sektor pertanian kurun waktu tahun 2005-2009 sebesar $68.07 \%$ dan pertumbuhan di sektor pertanian secara nominal sebesar 3,791,853.33 juta.

Kedua selanjutnya strukutur perekonomian terhadap PDRB adalah sektor perdagangan, hotel, dan restauran pada tahun 2005 memiliki kontribusi terhadap PDRB di Kabupaten Jember sebesar $19.35 \%$ dan selanjutnya pada tahun 2009 kontribusi pada sektor ini menunjukkan adanya kenaikan sebesar $0.66 \%$ menjadi $20.01 \%$ untuk laju pertumbuhan secara agregate di sektor perdagangan, hotel, dan restauran kurun waktu tahun 2005-2009 sebesar 77.68\% dan pertumbuhan secara nominal sebesar $1,872,817.68$ juta.

Ke tiga adalah sekor jasa-jasa pada tahun 2005 memiliki kontribusi terhadap PDRB di Kabupaten Jember sebesar $9.84 \%$ dan selanjutnya pada tahun 2009 kontribusi pada sektor ini menunjukkan adanya kenaikan sebesar $0.19 \%$ menjadi $10.03 \%$ untuk laju pertumbuhan secara agregate di sektor jasa-jasa kurun waktu tahun 2005-2009 sebesar $75.07 \%$ dan pertumbuhan secara nominal sebesar 920,601.66 juta.

Ke empat adalah sektor industri pengolahan pada tahun 2005 memiliki kontribusi terhadap PDRB di Kabupaten Jember sebesar $7,42 \% \%$ dan selanjutnya pada tahun 2009 kontribusi pada sektor ini menunjukkan adanya penurunan sebesar $0.03 \%$ menjadi $7,39 \%$ untuk laju pertumbuhan secara agregate di sektor industri pengolahan kurun waktu tahun 2005-2009 sebesar $71,23 \%$ dan pertumbuhan secara nominal sebesar $658,636.20$ juta.

Ke lima adalah sektor keuangan, persewaan bangunan dan jasa perusahaan pada tahun 2005 memiliki kontribusi terhadap PDRB di Kabupaten Jember sebesar 6,22\%\% dan selanjutnya pada tahun 2009 kontribusi pada sektor ini menunjukkan adanya kenaikan sebesar $0.15 \%$ menjadi $6,37 \%$ untuk laju pertumbuhan secara agregate di sektor keuangan, persewaan bangunan dan jasa perusahaan kurun waktu tahun 2005-2009 sebesar 75,863\% dan pertumbuhan secara nominal sebesar 587.939,95 juta.

Ke enam adalah sektor pengangkutan dan komunikasi pada tahun 2005 memiliki kontribusi terhadap PDRB di Kabupaten Jember sebesar 4,48\% dan selanjutnya pada tahun 2009 kontribusi pada sektor ini menunjukkan adanya penurunan sebesar $0.03 \%$ menjadi $4,45 \%$ untuk laju pertumbuhan secara agregate di sektor pengangkutan dan komunikasi kurun waktu tahun 2005-2009 sebesar 70,97\% dan pertumbuhan secara nominal sebesar 395.755,40 juta.

Ke tujuh adalah sektor pertambangan dan penggalian pada tahun 2005 memiliki kontribusi terhadap PDRB di Kabupaten Jember sebesar 3,92\% dan selanjutnya pada tahun 2009 kontribusi pada sektor ini menunjukkan adanya penurunan sebesar $0.12 \%$ menjadi $3,80 \%$ untuk laju pertumbuhan secara agregate di sektor pertambangan dan penggalian kurun waktu tahun 2005-2009 sebesar 66,88\% dan pertumbuhan secara nominal sebesar 326,293.17 juta.

Ke delapan adalah sektor bangunan pada tahun 2005 memiliki kontribusi terhadap PDRB di Kabupaten Jember sebesar 3,20\% dan selanjutnya pada tahun 2009 kontribusi pada sektor ini menunjukkan adanya peningkatan sebesar $0.13 \%$ menjadi $3,33 \%$ untuk laju pertumbuhan secara agregate di sektor industri pengolahan kurun waktu tahun 2005-2009 sebesar 78,63\% dan pertumbuhan secara nominal sebesar 313.407,17 juta.

Ke sembilan adalah sektor listrik dan air bersih pada tahun 2005 memiliki kontribusi terhadap PDRB di Kabupaten Jember sebesar 0,87\% dan selanjutnya pada tahun 2009 kontribusi pada sektor ini menunjukkan adanya peningkatan sebesar $0.03 \%$ menjadi $0,90 \%$ untuk laju pertumbuhan secara agregate di sektor industri pengolahan kurun waktu tahun 2005-2009 sebesar $78,27 \%$ dan pertumbuhan secara nominal sebesar $84.921,88$ juta. 


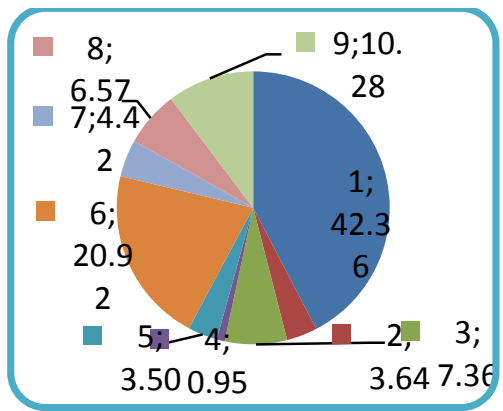

Keterangan :

Sektor :

1. Pertanian

2. Pertambangan dan Penggalian

3. Industri Pengolahan

4. Listrik Dan Air Bersih

5. Bangunan

6. Perdagangan, Hotel Dan Restoran

7. Pengangkutan Dan Komunikasi

8. Keuangan, Persewaan Bangunan Dan Jasa Perusahaan

9. Jasa - Jasa

Perkembangan Struktur Ekonomi Kabupaten Jember Atas Dasar Harga Berlaku Tahun 2005-2009

Perkembangan struktur ekonomi dapat dilihat menurut kelompok sektor yang meliputi kelompok sektor primer (meliputi sektor pertanian dan sektor pertambangan dan penggalian), Kelompok sektor sekunder (meliputi sektor industri pengolahan, sektor listrik dan air bersih,
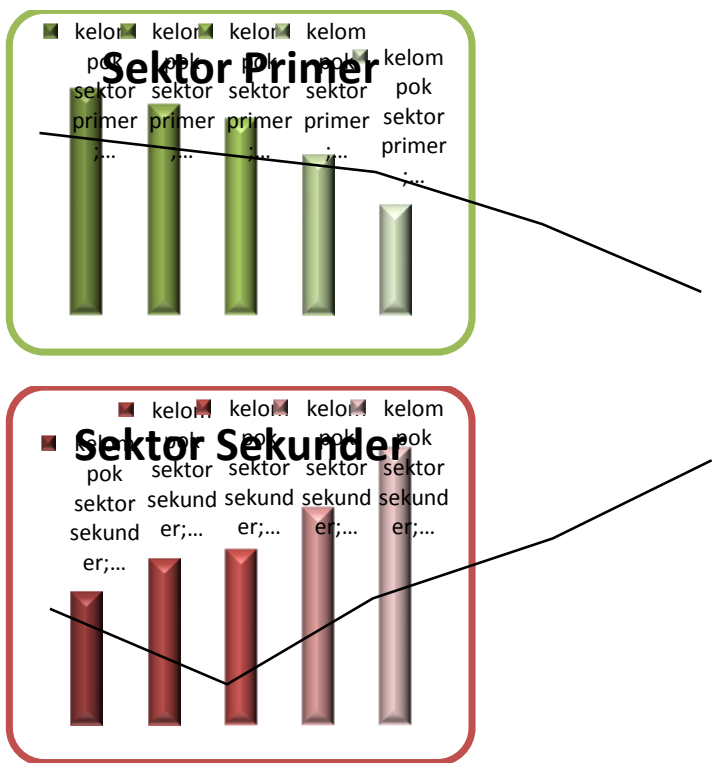

Selama periode 2005-2009, perekonomian Kabupaten Jember menunjukkan adanya pergeseran struktur ekonomi (economic structural transformation). Terlihat bahwa kelompok sektor primer (sektor pertanian dan sektor pertambangan dan sektor bangunan) dan sektor tersier (meliputi sektor perdagangan, hotel dan restoran, sektor pengangkutan dan komunikasi, sektor keuangan

, persewaan dan jasa perusahaan, sektor jasa-jasa). Adapun perkembangan struktur ekonomi Kabupaten Jember atas dasar harga berlaku Tahun 2005-2009 menuruta kelompok sektor dapat disajikan pada Grafik berikut :

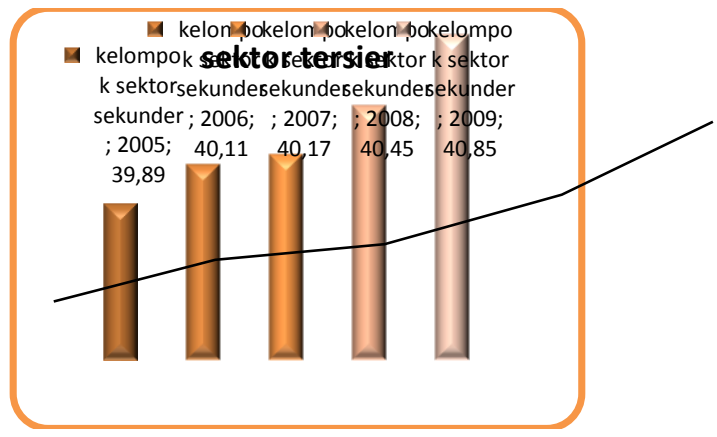

dan penggalian) mengalami trend penurunan kontribusi. Seiring dengan hal itu, kontribusi kelompoks ektor tersier (sektor perdagangan, hotel dan restoran, sektor pengangkutan dan komunikasi, sektor keuangan, persewaan, jasa 
perusahaan serta sektor jasa-jasa) meningkat.

\section{KESIMPULAN DAN SARAN KESIMPULAN}

Dari hasil penelitian dan perhitungan hasil analisis LQ pada sektor perekonomian (lapangan usaha) kabupaten jember dalam kurun waktu tahun 2005 - 2009 diperoleh kesimpulan sebagai berikut:

1. Hasil analisis LQ menunjukkan bahwa sektor pertanian masih merupakan sektor yang diunggulkan untuk di wilayah Kabupaten Jember karena 4 (empat) dari Sembilan sektor lapangan usaha yang ada di Kabupaten Jember kurun waktu tahun 2005-2009 sektor pertanian merupakan sektor basis yang memiliki nilai LQ paling tinggi dengan rata-rata sebesar 2,64 sehingga menunjukkan LQ > 1 dan selama periode tahun 2005-2009 sektor pertanian mempunyai kontribusi yang besar terhadap pembentukan PDRB.

2. Dilihat dari hasil analisis shift share mengindikasikan bahwa sumbangan/ kontribusi masing-masing sektor di Kabupaten Jember tidaklah sama. selama kurun waktu tahun 2005-2009 struktur perekonomian masih dominan di sektor pertanian dibandingkan dengan sektor-sektor yang lain. Kontribusi sektor pertanian pada tahun 2005 sebesar $44.71 \%$ terhadap PDRB dan pada tahun 2009 kontribusi sektor pertanian mengalami penurunan menjadi sebesar 43.73\% mengalami penurunan hanya sekitar $09.8 \%$, untuk laju pertumbuhan secara agregate di sektor pertanian kurun waktu tahun 2005-2009 sebesar $68.07 \%$ dan pertumbuhan di sektor pertanian secara nominal sebesar $3,791,853.33$ juta.

\section{SARAN}

1. Perubahan struktural dari perekonomian tradisional ke perekonomian modern telah menyebabkan pergeseran penyerapan tenaga kerja dan kontribusi PDRB di Kabupaten Jember sehingga Pemerintah Daerah agar lebih cermat dalam melihat transformasi ekonomi yang terjadi di Kabupaten Jember

2. Pembangunan ekonomi di Kabupaten Jember juga seharusnya memperhatikan pada pergeseran struktur ekonomi, seperti sektor pertanian yang mulai mengalami pergeseran penurunan tenaga kerja dan konstribusi PDRB akibat transformasi struktur ekonomi dari tradisional ke perekonomian modern..

\section{DAFTAR PUSTAKA}

Amir Hidayat dan Nazara Suhasil, 2005.Analisis Struktur Ekonomidan Kebijakan strategi pembangunan Jawa Timur tahun 1994-2000. Jurnal Ekonomi Pembangunan Indonesia : LPFE UI. http://www.plugin-04economic-landscape-jepijan-2005/

Arsyad, L. 1999. Ekonomi Pembangunan, Edisi Keempat. Sekolah Tinggi IlmuEkonomi. Yogyakarta.

Badan Perencanaan Pembangunan Daerah Kabupaten Jember. 2010, Jember Dalam Angka Tahun 2010

Badan Pusat Statistik (BPS), Jawa Timur Dalam Angka 2004-2009. Provinsi Jawa Timur. Angka 2004-2010, Kabupaten Jember Dalam Angka

Jhingan, M.L, 2003. Ekonomi Pembangunan dan Perencanaan. Jakarta: PT Raja Grafindo Persada.

Ketut Kariyasa, 2001. Perubahan Struktur Ekonomi dan Kesempatan Kerja Serta Kualitas Sumber Daya Manusia di Indonesia.Pusat Analisis Sosial Ekonomi dan Kebijakan Pertanian Bogor.http://www.(2)socakariyasastrktr/

Kuncoro, M. 2000. Ekonomi Pembangunan, Teori, Masalah dan Kebijakan, Edisi Kedua. Yayasan Keluarga Pahlawan Negara. Yogyakarta.

Lincolin Arsyad, 1999. Pengantar Perencanaan dan Pembangunan Ekonomi daerah.. Yogyakarta: BPFE.

Prasetyo Soepomo, 1993. Analisis Shift-share, Perkembangan dan Penerapan,Jurnal Ekonomi dan Bisnis Indonesia.

Ricardson, H.W. 2002.Dasar-dasar Ilmu Ekonomi dan Regional.FakultasEkonomi Unversitas Indonesia. Jakarta.

Robinson Tarigan, 2003. Ekonomi Regional, Medan: Bumi Aksara.

Robinson Tarigan, 2005. Ekonomi Regional Teori dan Aplikasi. Bumi Aksara. Jakarta.

Sadono Sukirno, 1994. Pengantar Teori Makro 